\title{
Konstruksi Isu Politik Melalui Jurnalisme Satire Di Media Online: Analisis Pemberitaan Isu \#2019Ganti Presiden di MOJOK.CO
}

\author{
Nani Yulianti \\ Fidikom UIN Syarif Hidayatullah Jakarta \\ Bintan Humeira \\ bhumeira@ymail.com \\ Fidikom UIN Syarif Hidayatullah Jakar ta
}

\begin{abstract}
ABSTRAK
Praktik jurnalisme identik dengan tanggung jawab media mengungkap kebenaran melalui bahasa. Kelugasan bahasa dalam menyampaikan pemberitaan menjadi penting untuk menyajikan fakta secara jelas. Penggunaan satire dalam praktik penulisan berita menjadi hiburan bagi pembaca. Akan tetapi disisi lain, gaya bahasa satire yang tidak lugas menunjukkan fakta rentan terhadap munculnya interpretasi yang tidak tepat oleh pembaca. Artikel ini bertujuan untuk melihat bagaimana penggunaan satiredalamkontruksi isu\#2019GantiPresidendi media online Mojok.Co. Artikel ini menggunakan paradigma konstruktivis dan tehnik analisa semiotika untuk melihat bagaimana kontruksi isu yang dibangun oleh Mojok.Co tentang isu \#2019GantiPresiden melalui penggunaan gaya bahasa satire. ArtikelinimenunjukkanbahwagayabahasasatiredigunakanMojok.Countukmenyerangkelompok pendukung isu \#2019GantiPresiden secara umum, dan calon presiden yang beroposisi dengan kekuasaan. Penggunaan gaya bahasa satire sebagai praktik jurnalistik tampak jelas mengarah pada cara media membangun sentimen politik pada kelompok lain daripada menyampaikan kebenaran atas fakta.
\end{abstract}

Kata kunci: Satire, \#2019GantPresiden,Media Online, Jurnalisme

Permalink/DOI: http://doi.org/10.15408/jsj.v1.13951

\section{A. PENDAHULUAN}

Menurut Badudu(1988) jurnalistikmemiliki karakteristik khusus dalam penggunaan bahasa yaitu singkat, padat, sederhana, lugas, menarik, lancar dan jelas. Dalam praktik jurnalisme, bahasa merupakan alat menyampaikan fakta untuk mengungkap kebenaran. Penggunaan gaya bahasa satire yang umumnya hadir dalam tulisan sastra dalam genre komedi, biasanya berupa sindiran, menciptakan sebuah pendekatan baru yangbeberapaahli menyebut sebagai jurnalisme komedi. Satire biasanya disampaikan dalam bentuk ironi, sarkasme, atau parodi. oleh karena itu ketika jurnalisme disandingkan dengan komedi, ada paradoks antara tugas jurnalisme menyampaikan fakta secara lugas dan jelas, dengan fungsi komedi untukmenghiburdenganpermainanbahasayang sarat sarkasme dan parodi yang rawan menimbulkan 
disinformasi atau misinformasi.

Kemunculan jurnalisme satire dianggap sebagai cara untuk melawan hegemoni kekuasaan dominan yang cenderung otoriter melalui kritik berupa sindiran atau parodi. Jurnalisme satire yang menghibur mulai marak seiring dengan kejenuhan publik dengan berita serius, dan melihat bahwa sajian dalam bentuk hiburan lebih menarik. Tingginya minat penonton akan beritayangmeghiburditunjukkanolehhasil Pew Survey (2004) yang memperlihatkan penonton kaum muda dan dewasa menyukai acara komedi tengah malam yang berisi tentang isu politik. Acara itu dilihat bukan hanya sekedar sebagai sumber hiburan, tetapi juga kesempatan untuk menambahkan kesadaran politik. Dengan alasan ini, Geoffrey Baym (2006) menyarankan agar acara yang menggunakan satire politik, seperti The Daily Show, harus dipertimbangkan sebagai bentuk jurnalistik alternatif. Memanfaatkan satire telah terbukti menjadi fitur yang menarik dalam pemrograman berita, khususnya bagi kelompok khalayak yang kurang terlibat secara politik. Selain itu tayangansatirepolitikmemainkanperandalam mengkritik kekuasaan yang seringkali represif terhadap kritik terbuka. ${ }^{1}$

Satire dalam pemberitaan politik marak munculdalammediaonline. Halinikarenaaspek kebebasan dan demoratisasi yang ditawarkan oleh internet bagi semua pengguna untuk bertindak sebagai konsumen atau produsen konten. Selain itu, keragamankonten dancarapenyajiankonten menjadiaspekpenting tidakhanyabagipembaca maupun juga bagi pembuat berita untuk menarik khalayak dalam merebut pehatian di ranah online. Salah satunya menggunakan gaya bahasa satire yang menghibur.

Salah satu media yang kerap menggunakan gaya bahasa satire adalah mojok.co. Penggunaan satire

${ }^{1}$ Geoffrey Baym, The Daily Show:Discursive Integration and the Reinvention of Political Journalism, Political Communication, (Taylor \& Francis Inc: 2006) 22: h.259-276 olehmojok.cobanyakdigunakanuntukmengemas isu-isupolitik.Salahsatuisuyangmenjadiperhatian mediaadalahisugantipresidenyangmunculseiring dengan kampanye Pemilihan Presiden (Pilpres) 2019. Isu tentang ganti presiden bergulir seiring dengan munculnya hastag \#2019GantiPresiden, yang kemudian membesar menjadi sebuah gerakan masyarakat pendukung calon presiden yang oposisi pada kekuasaan. Ramainya perbincangan tentang \#2019GantiPresiden direspon oleh Mojok.co dengan menerbitkan 38 artikel berlabel \#2019GantiPresiden sejak bulan April sampai dengan Oktober 2018 dengantotal 12.913 shares pada 10 September 2018. Hal ini menunjukkan bahwa jauh sebelum 2019, media sudah ramai memperbincangkan isu isu pilpres sebagai konten politik.

Banyaknya media yang memberitakan tentang \#2019GantiPresiden sudah tentu memiliki pandangan dan presepsi yang berbeda. Hal tersebut dapat dilihat melalui bagaimana gaya bahasa, pilihan kata maupun kalimat yang digunakanpadapemberitaantersebut.Pemberitaan \#2019GantiPresidenmerupakanberitayangcukup kontroversial mengingat sedang memanasnya dunia perpolitikan di Indonesia. Sudah menjadi barang tentu bahwa menuliskannya adalah sebuah tantangan yang harus dilakukan oleh seorang wartawan untuk menyajikan sebuah berita yang aktual dan faktual serta berimbang.

Penggunaansatireolehmojok.coterkaitdengan isu 2019GantiPresiden menimbulkan pertanyaan bagaimana penggunaan satire oleh mojok.co untuk mengkontruksi isu politik terkait dengan wacana 2019GantiPresiden, danmaknaapayang dikonstruksi oleh mojok.co tentang 2019Ganti Presiden.

\section{B. KERANGKA TEORI}

Jurnalistik secara praktis adalah proses pembuatan informasi hingga penyebarluasannya 
melalui media massa, baik melalui media cetak, elektronik,maupunmediaonline.Praktikjurnalistik merupakan cara-cara yang digunakan oleh intitusi mediauntukmengemaspemberitaansesuaidengan kodeetik jurnalistik dannilaiberita. Penggunaan satire dalam praktik jurnalistik dilihat sebagai konsep Jurnalisme komedia. Komedi memiliki artisandiwararinganyangpenuhdengankelucuan meskipun kadang-kadang kelucuan itu bersifat menyindir dan berakhir dengan bahagia; drama ria. ${ }^{2}$ Jurnalisme komedi karena menggunakan istilah "komedi" tidak memiliki arti bahwa jurnalisme yang digunakan menggunakan teknik sandiwara, tetapi lebih menekankan kepada bagaimana sebuah beritadibawakandenganringanyangpenuhdengan kelucuan meskipun kadang-kadang kelucuan itu bersifat menyindir (satire).

Jurnalisme komedi menggunakan salah satunya adalah gaya bahasa satire. Biasanya penggunaan satire ditujukan untuk menyampaikan sebuah beritayangdimaksudkan mengkritikkekuasaan. Jurnalisme komedi memiliki ciri yaitu penggunaan materiberitayangterbitdimediamainstreamdiolah menjadi sebuah perbincangan atau tulisan yang bernuansakomedi,atauadayangmenyebutsebagai news on news. Jurnalisme komedi kerap melakukan wawancara langsung kepada politikus, public figuresuntuk mengomentari isu yang sedang hangat diangkat oleh media. Dalam jurnalisme komedi, sekatperbedaanhiburandanberitamenjadikabur ataumelebur,danapabilamediakerapmenyajikan berita hiburan ini layaknya seperti hard news, maka cepat atau lambat batas perbedaan berita dan hiburan tidak akan terlihat.

Satire adalah gaya bahasa yang dipakai dalam kesusastraan untuk menyatakan sindiran terhadapsuatukeadaanatauseseorang. ${ }^{3}$ Menurut KerafsepertidikutipdalamTarigan,satireadalah ungkapan yang menertawakan atau menolak

\footnotetext{
${ }^{2}$ https://kbbi.web.id/komedi diakses pada 8 Maret 2019 pukul 15.57

${ }^{3}$ https://kbbi.web.id/satire diakses pada 8 Maret 2019 pukul 15.59
}

sesuatu.Bentukinitidakharusbersifatironis.Satire mengandung kritik tentang kelemahan manusia. Tujuan utamanya adalah agar diadakan perbaikan secara etis maupun estetis. ${ }^{4}$

AbramsdalamAllendan Stephens, membagi satire menjadi dua jenis berdasarkan bentuk pengungkapannya, yaitu Direct Satire berupa sindiran langsung adalah komentar terhadap seseorang atau sesuatu dengan mengungkapkan sindiran secara langsung, dan Indirect Satireberupa komentar terhadap seseorang atau sesuatu dengan cara mengungkapkan sindiran secara tidaklangsung.

LeBeoeuf menungkapkan bahwa karakteristik satire secara umum adalah sebagai berikut : (a) Mengandung kritik, (b) Bersifat Ironis, (c) Implisit; dan (d) mendekonstruksi dengan cara melebih-lebihkan, absurd, atau keluar dari konteks normalnya. Unsur-unsur satire menurut Abrams dalam Octa yaitu : (a) Parodi, (b) Ironi (Verbal Irony, Sarcasm, Socratic Irony, Dramatic Irony, Cosmic Irony) (c) Alegori, (d) Humor

Salah satu riset tentang penggunaan satire dalampemberitaanpolitikdilakukanolehHoffman, yang melihat politik satire dalam jaringan sosial. Penelitian ini membahas tentang bagaimana efektivitas ajakan yang dilakukan oleh TV Show Last Week Tonight with John Oliver mendorong penontonnya untuk berpartisipasi dalam politik. TV Show Last Week Tonight with John Oliver adalah sebuah acara yang disiarkan di televisi di Amerika yang mengangkat dan menggunakan tema satire sebagai pokok utama dari acaranya. Satire di sini digunakan untuk mengomentari hal-hal atau pun isu terkait dengan politik yang tengah terjadi di Amerika. Riset ini meggunakan pendekatan kuantitaifdan menghasilkan temuan bahwa penonton yang melihat acaranya sampai pada bagian ajakan berpartisipasi dalam politik lebih banyak mendapatkan pengetahuan tentang

\footnotetext{
${ }^{4}$ Yanty Nuryanah, Satir Dalam Kumpulan Cerpen Kuda Terbang Maria Pinto Karya Linda Christiany dan Implikasinya Terhadap Pembelajaran Bahasa dan Sastra Indonesia, (Jakarta: 2017), h.22
} 
dunia politik, dibandingkan penonton yang tidak menonton sampai pada bagian ajakan. Riset ini juga menunjukkan bahwa humor memiliki efek signifikan meningkatkan partisipasi politik melalui jaringan media sosial.

Selain itu riset oleh Abusmishan memfokuskan pada pilihan mahasiswa Universitas Illinois di Chicago untuk belajar politik dari kelas atau dari menonton acara televisi yang menggunakan satire, dan mengetahui apakah mahasiswa belajar dengan baik ketika mereka terpapar informasi sekaligus dihibur dalam waktu yang bersamaan. Hasil riset menunjukkan bahwa lima dari enam nara sumber yang diwawancara tentang menyebutkan bahwa mereka menjadikan acara televisi Last Week Tonightwith John Oliver sebagai yang terfavorit. Hal ini karena format acara dan gaya presentasi yang disuguhkan. Acara televisi ini juga dianggap menyuguhkananalisismendalam tentangpolitik yang tengah berkembang dengan sebisa mungkin meminimalisir bias. Hal ini menunjukkan bahwa komedian satire mendapatkan banyak perhatian dari para generasi muda di Amerika Serikat terkait dengan isu politik. Hal ini bukan hanya untuk menjadibahantertawaan, tetapijugabahanbelajar bagi para milenial.

\section{METODOLOGI}

Dalam penelitian ini penulis menggunakan paradigma konstruktivis. dengan pendekatan kualitatifuntukmenemukanbagaimanamojok,co sebagai media online melakukan pembingkaian isu politik tentang wacana ganti presiden 2019 melalui penggunaan gaya bahasa satire. Analisis menggunakan semiotika Charles S. Sausure pada teks berita di mojok.co pada bulan April, Mei dan Agustus 2018 yang mengusung tagar \#2019GantiPresiden. Analisis semiotika digunakan untuk mengetahui makna yang dikontruksi atas wacana tersebut dan mengidenfikasi jenis satire apa yanglebihdominandigunakanolehmojok.countuk
melakukanpembingkaianisu.Selainitupenelitian ini juga menggunakan analisis sintagmatik yang mencari arti secara harfiah dari sebuah kata dan analisis paradigmatik yang mengartikan makna kata secara eksternal dalam penggunaannya saat berkomunikasi.

\section{HASIL DAN PEMBAHASAN}

Isu \#2019GantiPresiden dicetuskan pertama kali oleh politikus Partai Keadilan Sejahtera(PKS), yaitu MardaniAli SeradiakunTwitterpribadinya. \#2019GantiPresiden meramaikan media sosial karena menuai beragamkomentar darikhalayak. Data Drone Empirit dalam Viva.co.id, tercatat sejak 1 sampai10 April2018\#2019GantiPresiden mendapat 110 ribu mention di Twitter. Ramainya tagar ini di media sosial, kemudian menjadi isu hangatyangdiangkat ke media lain seperti cetak, elektronik, maupun online.

Salahsatumediaonlineyangmengangkatisu iniadalahMojok.co.Mojok.coadalahsebuahmedia onlineyang berbasis di Yogyakarta dan berdirisejak tahun 2014. Mojok.co menerbitkan artikel dengan tags \#2019GantiPresiden dengan gaya tulisan satire. Artikeldengan\#2019GantiPresidendiMojok.co berjumlah 38 artikel terhitung sejak bulan April sampaidenganbulan Oktober 2018, tetapidalam penelitianinipenulishanyamengambiltigasampel artikel yang memiliki shares cukup banyak dan sesuai dengan kriteria satire yang akan dibahas.

Artikeliniakan menjelaskanhasildalam dua bagian yaitu hasil analisis teks dan interpretasi hasil penelitian. Analisis teks pada bulan April, Mei dan Agustus menunjukkan temuan menggunakan tiga artikel dalam mojok.co pada bulan April, Mei dan Agustus 2018. Analisis pada tiga artikel menunjukkan hasil sebagai berikut:

Pada artikel bulan April 2018, mojok.co menggunakan judul "Merenungi Aksi Bullying Massa\#2019GantiPresidendiArenaCarFreeDay" 
. Dariaspek tanda, mojok.commenggunakan teks berikut :

"Yah, melihat video sekelompok orang yang membully ibu dan anaknya karena alasan perbedaan pandangan politik itu, besar kemungkinan, setan pasti bahagia sekaligus sedih. Bahagia karena bisa membuat manusia terpecah belah. Dan sedih karena ternyata mereka kalah jahat dari manusia."

Acuantandayangdigunakanadalahkegiatan perundungan yang dilakukan oleh sekelompok orang yang menggunakan kaus dengan \#2019GantiPresiden kepada ibu dan anak yang menggunakan kaus \#DiaSibukKerja yang terpisah dari rombongan dalam acara Car Free Day. Dua cauan tanda ini menunjukkan ada perundungan yangdilakukanolehkelompokpendukungwacana \#2019gantipresiden yang direpresentasikann sebagai pendukung calon presiden Prabowo, terhadap kelompok pengguna kaos \#Diasibukkerja yang mewakili pendukung Capres Jokowi. Teks menunjukkan kecenderungan mojok untuk menyatakan sikap kritik kepada pengguna kaus \#2019GantiPresidenyangmelakukanperundungan.

Artike ini menunjukkan mojok.co juga menggunakan direct satire dalam tulisaninidengan memberikan penyebutan subyek secara halus sebagai "sekelompok orang" yang masuk ke dalam socratic irony.Mojok.co menggunakan perumpamaan "setan" yang dituju kepada pendukung wacana 2019GantiPresiden atau pendukung capres Prabowo Subianto. Penyebutan "setan" sebagai pelaku perundungan sebagai sebuah bentuk dari gaya bahasa sarkasme.

Dalam teks ini juga tampak Mojok.co juga menggiring opini kepada pembaca bahwa pendukung capres Prabowo Subianto adalah kelompok yang membuat masyarakat Indonesia terpecahbelahmenjelangpilpres,danmenekankan kesan dibagian akhir bahwa pendukung capres Prabowo Subianto jauh lebih jahat dari setan.
Dari teks tersebut tampak bahwa mojok.co mengkontruksi gerakan \#2019GantiPresiden sebagai sebuah gerakan yang mengintimidasi kelompok lain yang berbeda pandangan. Nada sentimen tampak jelas dalam teks dengan sindiran bahwa apa yang dilakukan melebihi perilaku setan.

Analisis Teks pada artikel "Relawan \#2019GantiPresiden Rencanakan Mudik Bareng Lewat Tol Era Presiden Yang Mau Diganti” pada bulanMei2018 menunjukkanaspektandasebagai berikut :

"Benci demokrasi tapi berlindung dengan tameng demokrasi, seperti ingin sebar gerakan ganti Presiden tapi memanfaatkan fasilitasfasilitas yang disediakan Presiden. Yaboleh sih, itu tidak melanggar hukum, sah secara aturan, dan memang sudah menjadi hak warga negara. Hanya saja kalau kata SpongeBob SquerePants ini namanya; "ironi di atas ironi."

Acuan tanda dari teks tersebut adalah sikap kontra gerakan \#2019GantiPresiden (pendukung capres Prabowo Subianto) terhadap presiden yang tengahmenjabat, untukkemudianmenggantinya pada pilpres 2019. Sikap kontra ini dilakukan melalui banyak kegiatan yang dilakukan oleh gerakan \#2019GantiPresiden, mulai dari melakukan deklarasi di berbagai daerah sampai pada kegiatan mudik bersama. Mudik bersama ini dilakukan dengan tujuanuntuk menyebarluaskan semangat ganti presiden sampai ke pelosok negeri.

Dengankatalain,acuantandainimengacupada aktivitas perilaku pendukung \#2019GantiPresiden yang melakukan mudik hari raya menggunakan jalan tol, yangdiidentikan sebagaihasilpembangunan yangdilakukanPresidenyangakanmerekaganti. Kata-kata "benci demokrasi tapi berlindung dengantamengdemokrasi"menyindirkelompok pendukung 2019Ganti Presiden yang dianggap melakukan tindakan inkonstusional dengan menggaungkan pergantian presiden sebelum masuk masa kampanye Pilpres. 
Sedangkan proposisi kedua berbunyi "seperti ingin sebar gerakan ganti Presiden tapi memanfaatkan fasilitas-fasilitas yang disediakan Presiden”. Proposisi ini jelas ditujukan kepada pendukung capres Prabowo Subiantoterkaitgerakan\#2019GantiPresidenyang akan melakukan mudik bersama.

Mojok.co menggabungkan dua proposisi yang bertentangan dengan logika demi menggiring pembaca kepada pemahaman baru. Dapat dikatakan bertentangan logika karena Mojok.co dengan sengaja menggabungkan dua subjek yang berbeda dalam konteks yang berbeda juga, tetapi tetap disatukan dalam satu kalimat.

Mojok.co juga menggunakan konjungsi perbandingan dengan menggunakan kata seperti. Dari konjungsi dua proposisi dari kalimat ini, penulis interpretasikan bahwa Mojok.co berusaha menggiring pembaca untuk mengartikan bahwa benci demokrasi pada proposisi pertama ditujukan kepadapendukungcapresPrabowoSubiantoyang beradadiproposisikedua.Halinikarenapendukung capresPrabowoSubiantoinginmenggantipresiden yang tengah menjabat tetapi tetap menggunakan fasilitas berupa jalan tol yang dibangun di masa presiden yang ingin diganti.

Teks tersebut bahkan melakukan sindiran yang digunakan sebagai klaim bahwa kelompok pendukung 2019GantiPresiden sebagai kelompok yang melanggar hukum karena menggunakan fasilitas milik pemerintah yang mereka ingin ganti dengan pepimpin baru. Pernyataan mojok. co sebagai seakan-akan "pelanggaran hukum" membuat fakta menjadi tidak jelas dan kabur karena mengatakab bahwa masyarakat yang ingin memilih presiden baru tidak boleh memanfaatkan fasilitaspemerintah. Teksinimengabaikanfakta, pertamabahwatidakadahukumyangmengatakan masyarakat tidak boleh menggunakan fasilitas pemerintahyang tidakdipiliholehmerekadalam Pemilu. Kedua, mojok.co mengabaikan fakta bahwa hasil pembangunan sepenuhnya adalah milik rakyat karena menggunakan uang rakyat, bukan uang milik Presiden atau pemerinta yang berkuasa.

Dengandemikiansatireyangdigunakandalam teks ini bersifat tidak langsung dan secara sinis memojokan pendukung \#2109GantiPresiden sebagai kelompok yang tidah tahu aturan hanya karenamenginginkanpemerintahdigantinamun masih menggunakan fasilitas yang dibangunnegara.

Mojok.co menggunakan direct satire dalam artikel ini. Mojok.co melakukan kejanggalan logika dengan menganggap fasilitas jalan tol yang dibangun adalah milik pribadi Presiden.Mojok. co juga menggabungkan dua proposisi yang berbeda dengan maksud memberi pemahaman baru. Di mana Mojok.co menganggap pendukung \#2019GantiPresiden adalah orang yang benci demokrasi.

Mojok.cojuga melakukan pembenaran terhadap kegiatan mudik bersama dengan maksud melakukan ironi. Penggunaan istilah dari Spongebob juga menggambarkan bahwa Mojok.co menganggap \#2019GantiPresiden kekanak-kanakkan. Dengan demikian makna yang dikonstruksi oleh mojok.co terhadappendukungwacana\#2019GantiPresiden sebagai kelompok yang tidak tahu aturan karena menggunakan fasilitas yang dibangun oleh pemerintahyangingindigantiolehmerekadalam Pemilu 2019.

Selainkeduaartikeldiatas, artikel tentangisu ganti presiden tampak pada teks "Ahmad Dhani Yang Diusir Di Kampung Halamannya Sendiri" pada bulann Agustus 2018. Tanda yang muncul dalam teks sebagai berikut:

Kasihan ya, Dhani. Ternyata perbedaan pandangan politik, bisa menjadikan Ahmad Dhani diusir dari kampung halamannya sendiri, ya. Bahkan disuruh balikke tanah rantau lagi. Padahal kan biasanya, orang-orang yang sukses ditanahrantau,justrudimintauntukpulangke kampung halaman. Ini kok Atau yang mengusir Ahmad Dhani sebenarnya justru adalah fans Maia Estianty garis keras? 
Dari teks diatas tampak bahwa acuan tanda yang digunakan adalah aksi deklarasi \#2019GantiPresiden di Surabaya yang akan dilakukan oleh Ahmad Dhani. Ahmad Dhani adalah seorang musisi Indonesia dan juga salah satupolitikusdari Partai Gerindra. Partai Gerindra adalah partai yang mengusung dan mendukung Prabowo Subianto sebagai capres untuk kembali majudalampilpres2019.,sebagairivaldaripresiden Jokowi dalam Pilpres 2019. Sebagai salah satu politikusnya, Ahmad Dhani turut mendukung aksi \#2019GantiPresiden dengan melakukan deklarasi di kampung halamannya.

Dari teks tersebut tampak Mojok.co menggunakan direct satire yang dilakukan dengan nadacibiranataucemoohanyangditujukankepada Ahmad Dhani yang akan melakukan deklarasi \#2019GantiPresiden di Surabaya.

Mojok.co kembali mengungkapkan pendapat bahwa tidak sewajarnya orang rantau diusir dari kampung halaman seperti dalam tanda, "Padahal kan biasanya, orang-orang yang sukses di tanah rantau, justru diminta untuk pulang ke kampung halaman.Inikok '.Tandainiadalahpengulangan Mojok.co untuk kali ke tiga.

Pengulangan pernyataan dalam artikel ini menyiratkan bahwa pernyataan tersebut penting untukdiingatpembaca. Dalaminterpretasipenulis, pernyataaninimerupakansalahsatucaraMojok.co menggiring pemahaman bahwa sebenarnya Mojok. co mengkritik Ahmad Dhani yang mendukung gerakan\#2019GantiPresiden.PilihanAhmadDhani untukmendukunggerakan\#2019GantiPresiden, yang pada akhirnya membuatnya diusir dari kampung halamannya sendiri.

Dalamkalimatterakhirterdapatkatafans.Fans adalah kata dalam bahasa Inggris yang memiliki arti penggemar. Maia Estianty adalah mantan isteri Ahmad Dhani. Kata garis, berarti "coretan panjang". ${ }^{5}$ Kata keras, berarti“"padatkuatdantidak mudah berubah bentuknya atau tidak mudah pecah". ${ }^{6}$ Ketika kata garis disandingkan dengan kata keras, memiliki arti strategi untuk memperjuangkan pahamdenganperlawanan. Tetapidalamkalimat ini kata garis keras memiliki arti penggemar Maia Estianty yang fanatik.

Mojok.co juga menggunakan karakteristik satireberupaimplisityangmelebih-lebihkandan keluar dari konteks. Di mana topik penolakan Ahmad Dhani bukan semata karena perbedaan pandangan politik, tetapi juga karena penolakan dari penggemarberat mantanisteri Ahmad Dhani, yaitu Maia Estianty.

Hal ini dapat di lihat dari tanda "Atau yang mengusirAhmadDhanisebenarnyajustruadalahfans Maia Estianty garis keras,". Tanda ini mengarah ke urusanpribadisubjekartikel, yangjauhdarifakta dilapangankarenatidakditemukannyadatayang validterhadappenolakanterhadap AhmadDhani di Surabaya yang disebabkan oleh penggemar Maia Estianty.

Dalam interpretasi penulis, makna yang ingin dibangun oleh Mojok.co melalui artikel ini adalah Mojok.co mengkritik Ahmad Dhani yang mendukung gerakan\#2019GantiPresiden. SehinggaMojok.comembuatartikelsatiretentang Ahmad Dhaniyangbertujuanuntuk mencemooh Ahmad Dhani terhadap pilihan politiknya.

Mojok.co juga melakukan sebuah satire implisit yang keluar jauh dari konteks dan menjadikannya opini yang bersifat menyerang personal, namun ditujukan untuk menyindir kelompokpendukung\#2019GantiPresidensecara keseluruhan. Penggunaan teks "Atau yang mengusir Ahmad Dhani sebenarnya justru Aladdin fans Maia Estianty garis keras?" merupakan sindiran pada tokok Ahmad Dani sebagai politikus Gerindra,

\footnotetext{
${ }^{5} \mathrm{https}: / / \mathrm{kbbi}$.kemdikbud.go.id/entri/garis diakses pada 6 September 2019 pukul 16:56

${ }^{6} \mathrm{https} / / / k b b i . k e m d i k b u d . g o . i d / e n t r i / k e r a s$ diakses pada 6 September 2019 pukul 16:57
} 
partaipendukungPrabowo,terkaitdenganmasalah pribadi tokok yang sebenarnya tidak berkaitan dengan wacana \#2019GantiPresiden. Namun, sebagai pesohor, kisah pribadi Ahmad Dani menjadikonsumsipublik.Kisahkekisruhanrumah tanggatokohinikemudiandijadikancaramojok. co memberikan sindiran bahwa tokoh pendukung wacana \#2019GantiPresiden adalah sosok yang bermasalah juga dalam kehidupan pribadinya.

Sebelum melihat penggunaan satire dari perspektif jurnalistik, perlu diketahui bahwa beberapapenelitianterdahulutentangpenggunaan satire dalam jurnalisme memberikan hasil yang positif. Penggunaan satire dipandang dapat meningkatkan fungsi kritikterhadap politik dan meningkatkan partisipasi masyarakat terhadap politik. Artinya, penggunaan satire dalam hal ini dianggapberdampakpositif,karenamembuatorang terhibur sekaligus meningkatkan pengetahuan politik. . Seperti yang dikemukakan olehJones dan Baym, bahwa sajian satire dalam tayangan berita politik membangun sebuah sistem demokrasi bagi warga dan sekaligus menyediakan saluran yang bermanfaat untuk keterlibatan dalam kehidupan bangsa.

Dari sisi jurnalistik, dengan menggunakan konsep jurnalisme komedi, Mojok.co seakan-akan ingin memberikan pilihan baru kepada khalayak dalampenyajiansebuahinformasi.DimanaMojok. co menyajikan informasi dengan menggunakan gaya bahasa satire berupa humor, parodi, atau sindiranuntukmenghiburmasyarakat.Akantetapi hasil analisis menemukan bahwa Mojok.co justru mengemasinformasidenganetikayangjauhdari koridor jurnalistik, yaitu menojokan, menyindir dan mengolok-mengolok pihak lain.

Sebagai sebuah media, citra yang ingin ditampilkan oleh Mojok.co kepada publik dalam menyajikan artikel adalah sebagai sebuah media yangmenyajikanartikeldengangaya menghibur dan juga tetap berimbang atau netral. Namun dari hasil penelitian yang dilakukan justru menunjukkan sikap berpihak pada kelompok penguasa dan menentang kelompok pendukung wacana\#2019GantiPresiden. Hal ini dapat dilihat dari penggunaan satire langsung yang dilakukan oleh Mojok.co.

Ketiga artikel yang dijadikan sampel dalam penelitianinimenggunakansatirelangsungyang oleh Mojok.coditujukankepadapendukungcapres Prabowo Subianto sebagai lawan politik Presiden yang sedang berkuasa. Penggunaan satire langsung ini tampaknya dilakukan untuk menggiring pembacanya untuk memeliki pandangan politik yang sama dengan Mojok.co.

Padahal sebagai sebuah media massa, Mojok. co seharusnya bersikap berimbang dengan tidak memihak kepada siapapun dalam urusan politik secara dominan, dan memojokan pihak lain dengantidakmemberikanruangyangsamauntuk memberikan pernyataan atau klarifikasi. Hal ini seperti yang dikatakan oleh Ketua Aliansi Jurnalis Independen (AJI), Abdul Maman, "Kami organisasi wartawanmemilikihakmoraluntukmengingatkan janganmenggunakanmediauntukpolitik. Karena media memilik tanggung jawab yang sangat besar untuk melayani kepentingan publik,"?

Hasil penelitian selanjutnya menemukan bahwa penggunaan satire oleh Mojok.co justru menggunakan kata sarkasme yang seharusnya tidak dilakukan oleh media. Sumadiria mengatakan bahwa bahasa jurnalistik tunduk kepada kaidah etis. Jadi bahasa jurnalistik terlarang menggunakan kata-katakasar,menyakitihati,tidakenakdidengar, vulgar, sarat sumpah-serapah, dan lebih jauh lagi mencerminkanpolaperilakuorang,ataukelompok masyarakat yang tidak beradab. Penggunaan gaya bahasa sarkasme ini tampak ketika Mojok.co menyamakan pendukung capres Prabowo Subianto dengan setan.

Penggunaangayabahasasarkasmedigunakan

\footnotetext{
${ }^{7}$ https://www.merdeka.com/peristiwa/punya-tanggungjawab-besar-ke-publik-media-harus-netral-di-pemilu-2019. html diakses pada 30 September 2019 pukul 22:13
} 
oleh Mojok.com sebagai sarana penggambaran terhadap pendukung capres Prabowo Subianto yang diasumsikan jahat, melanggar aturan dan tidak demokratis. Hal ini jelas ditujukan untuk menggiring opini pembaca untuk beranggapan negatif terhadap pendukung capres Prabowo Subianto. Apalagi dengan cara pengisahan yang dramatis bahwa kelompok pendukung wacana \#2019GantiPresidenlebihjahatdari setankarena telahmelakukanperundunganpadaperempuandan anak-anak hanya karena berbeda pilihan politik, sehingga membuat masyarakat Indonesia terpecah blah .

Padahal pelabelan yang diberikan dengan kata melanggar aturan dan tidak demorkratis misalnya tidak secara jelas menunjukkan pada aspek tersebut. Tidak ada hukum yang dilanggar secara resmi, tidak ada penjelasan apa yang dimaksud dengan sikap tidak demokratis dalam tulisan tersebut merujuk pada kelompok \#2019GantiPresiden. Artinya, penggunaan satire dalam tulisan justru lebih tampak sebagai sikap sentimenn mojok.co ataspilihanpolitiskelompoklainyangtidaksejalan dengan pilihan mojok.co yang jelas berpihak pada kekuasaan.

Mojok.co juga melakukan pembingkaian melaluipenggunaankata-katayangdipilihnya.Hal inibertujuanmengarahkanpikiranpembacakepada hal yang dikehendaki Mojok.co, yaitumenentang wacana \#2019GantiPresiden. Hal ini nampak ketikaMojok.comenggunakankata“'setan"yang dianggap sebagai representasi kelompok pendukung \#2019Ganti Presiden atau pendukung capres Prabowo Subianto. Pilihan kata yang dilakukan oleh Mojok.co penulis interpetasikan sebagai pembentukan realitas yang tidak berdasarkan fakta karena di dunia ini tidak ada yang tahu apa yang dilakukan oleh setan. Hall (1928) dalam Wibowo (2010:122) berpendapat bahwa berkenaan dengan eksistensi media massa, dewasa ini tidak lagimereproduksirealitasatautidaklagi menjadi wadah penyalur informasi, tetapi justru menentukan realitas atau melakukan pembingkaian melaluipemakaiankata-katatertentuyangdipilih. ${ }^{8}$

Pelabelan yang diberikan mojok.co atas kelompok \#2019GantiPresiden seperti bentuk propaganda media dalam rangka mendukung status quo. Harold D. Lasswell mengatakan propaganda dalam arti yang paling luas adalah teknik memengaruhi tindakan manusia dengan memanipulasi representasi (penyajian). Representasi bisa berbentuk lisan, tulisan, gambar, atau musik. ${ }^{9}$ Sebagai lembaga penyebar informasi kepada khalayak, menurut teori normatif media dalam Teori Komunikasi Massa McQuail, tidak dibenarkan media melakukan propaganda karena media sebenarnya ditujukan untuk kepentingan publik, bukan untuk membela kelompokkekuasaan.

Representasi yang disajikan mojok.co dalam sistem penandaan yang dibangun melalui penggunaan satire dalam tulisan menunjukkan bahwa pers tidak lagi bertindak sebagai agent of control atau wacthdog dari kekuasaan. Sebaliknya, media justru terlibat dalam membangun opini yang cenderung bersikap sentimen dan sinis atas kritik yang ditujukan kelompok yang mengeritik kekuasaan. Ini tentulah mencederai kepentingan publik yang seharusnya menjadi tanggungjawab sosial media.

PenelitianinijugamenunjukkanbahwaMojok. comenggunakansatire sebagaicaraimplisituntuk secara hiperbola atau berlebihan menggambarkan sebuahfaktayangkeluardarikontekspemberitaan. Bahkanbisajadjauhdarifaktayangadadilapangan. Hal ini tampak ketika Mojok.co menggunakan sosok selebritas yang juga sebagai politikus Partai Gerindra untuk membangun citra negatif terhadap pendukung capres Prabowo Subianto dengan menggunakan konteks yang tidak terkait dengan

\footnotetext{
8 Apriadi Jamburaka, Agenda Setting Media Massa, (Jakarta: PT Rajagrafindo Persada, 2012) h.85

9 Werner J, Severin dan James W. Tankurd Jr. Teori Komunikasi, Sejarah, Metode, dan Terapan di dalam Media Massa Edisi ke-5. (Jakarta: Kencana Prenada Media Group: 2005) h.128
} 
isudanmengarahkewilayahpribadi.Dengankata lain, ada kesengajaan yang dibangun oleh mojok.co untukmenggunakanisupribadiuntukmembangun kesan negatif secara umum terhadap kelompok lain. Padahal fungsi pers seharusnya senantiasa berusaha untuk menempatkan setiap fakta atau kumpulan fakta-fakta menurut proporsinya yang wajar (Severin dan Tankard, 2005).

Penggunaan satire implisit ini penulis interpretasikan bahwa Mojok.co mencederai Kode Etik Jurnalistik pada pasal 1 yang berbunyi "Wartawan Indonesia bersikap independen, menghasilkan berita yang akurat, berimbang, dan tidak beritikad buruk." dan pasal 3 yang berbunyi, "Wartawan Indonesia selalu menguji informasi, memberitakan secara berimbang, tidak mencampurkanfaktadanopiniyangmenghakimi, serta menerapkan asas praduga tak bersalah," ${ }^{10}$

Satire dalam kesusastraan biasanya dituangkan melalui karya tulisan baik berupa novel atau cerita pendek. Dalamsastra, satirisklasikyangterkenal antara lain Aristophanes, Horace, dan Juvenal, diikuti kemudian oleh Rabelais, Defoe, Swift, dan Voltaire(Shadily,1984:3040). ${ }^{11}$ Dalamjurnalisme komedi, penggunaan satire dalam bidang jurnalistik kembali populer di abad 21, berawal dari Amerika Serikat yang menggunakan satire dalam acara televisi seperti The Daily Showwith Jon Stewart. Mojok.co tampaknya ingin mengadopsi satire dengan menggunakan media tulisan.

Dari hasil analisis dapat dilihat bahwa satire yang dilakukan Mojok.co digunakan untuk menggiring opini pembaca untuk mendukung kepentingannya, dalam hal ini media sebagai bisnis.HalinisejalandenganpemikiranASHaris Sumadiriayangmengatakan,"Persterustumbuh tidak saja sebagaimedia komunikasi massa secara

\footnotetext{
${ }^{10} \mathrm{https}$ ://tirto.id/kode-etik-jurnalistik-8Nb diakses pada 11 September 2019 pukul 15:17

11 AS Haris Sumadiria, Jurnalistik Indonesia, Menulis Berita dan Featrue; Panduan Praktis Jurnalis Profesional. (Bandung: Simbiosa Rekatama Media, 2008) Cet. Ke-3, h.156
}

profesional, melainkan juga sebagai usaha bisnis."12

Seperti yang dikatakan oleh Malcom X bahwakekuatanmediasungguh luarbiasa dalam menggiring opini sesuaidengan keinginan media, seperti dalam pernyataannya "the media's the most powerfull entity on earth. They save the power to make the innocent guilty and to make the guilty innocent, and that's power. Because they control the minds of the masses, "13. Dari satire yang diteliti sangat memperlihatkan sikap dan posisi Mojok.

co terhadap kontestasi pilpres 2019, hal ini karena tanda memberikan ciri yang tinggi yang menggambarkanmaksuddanposisimedia.Dengan tandayang adadalam ketigasampelyang diteliti, terlihatbahwa Mojok.cokontraterhadapgerakan \#2019GantiPresiden.

\section{E. KESIMPULAN}

Hasil riset ini mengemukakan bahwa penggunaan satire dalam artikel \#2019GantiPresiden tidakefektifuntukdapatmenjadialternatifdalam menyajikan informasi mengenai kontestasi pilpres 2019karenapenggunaansatiretidaksesuaidengan kaidah jurnalistik. Penggunaan satire oleh Mojok.co dalam artikel ini tidak berimbang dan netral, dari tandayangdihasilkanmemperlihatkanposisinya dalam kontestasi pilpres.

Satire yang dilakukan oleh Mojok.co mengandung unsur sarkasme yang seharusnya tidak digunakandalambahasajurnalistik.Mojok.cojuga menggunakansatiresebagaialatpropagandauntuk mengonstruksi dan menggiring opini pembaca menujuapayang Mojok.comaknai. Mojok.cojuga mencederai Pasal 1 dalam Kode Etik Jurnalistik dalam poin "menghasilkan berita yang akurat" dan Pasal 3 dalam poin "tidak mencampurkan fakta dan opini”.

\footnotetext{
12 Marhaeni Fajar, IImu Komunikasi Teori dan Praktik, (Yogyakarta: Graha IImu, 2009) h.223

13 https://www.kompasiana.com/teguh01190/5c21930ba eebe15d1b63c767/netralitas-media-dalam-kontestasi-politik2019?page=all diakses pada 30 September 2019 pukul $12: 08$
} 
Dari ketiga sampel yang dijadikan bahan penelitian,terlihatpolayangsama,dimanaMojok. co selalu menempatkan tanda di akhir dariartikel yang merupakan bagian penutup dari sebuah peristiwa yang dilaporkan. Tanda tersebut yang memiliki kekuatan unsur satire dalam artikel yang menjadi praktik dari jurnalisme komedi. Dalam penelitian ini ditemukan satire yang digunakan adalah satire langsung.

Penggunaan satire langsung ditujukan untuk memojokkan pendukung capres Prabowo Subianto. Hal ini secara tidak langsung penulis simpulkan bahwa Mojok.co kontra terhadap gerakan \#2019GantiPresiden yang mendukung capres Prabowo Subianto.

\section{DAFTAR PUSTAKA}

Baym, Geoffrey. 2006. "The Daily Show:Discursive Integration and the Reinvention of Political Journalism, Political Communication”. Taylor \& Francis Inc.

Budiman, Kris. 2011. Semiotika Visual: Konsep, Isu, dan Problem Ikonitas. Yogyakarta: Jalasutra.

Fajar, Marhaeni. 2009.Ilmu Komunikasi Teoridan Praktik. Yogyakarta: Graha Ilmu.

Jambaruka, Apriadi. 2012. Agenda Setting Media Massa. Jakarta: PT Rajagrafindo Persada.

Kriyanto, Rachmat. 2007. Teknik Praktis Riset Komunikasi (Disertai Contoh Praktis Riset Media, Public Relations, Advertising, Komunikasi Organisasi, Komunikasi Pemasaran). Jakarta: Kencana Prenada Media Group.

Kusumaningrat,Hikmat.PurnamaKusumaningrat. 2005. Jurnalistik, Teori, dan Praktik. Bandung: PT Remaja Rosdakarya.

Severin, Werner J. James W. Tankurd Jr. 2005.

TeoriKomunikasi, Sejarah, Metode, dan Terapan di dalam Media Massa Edisi ke-5. Jakarta: Kencana Prenada Media Group.

Sumbadiria, AS Haris. 2008.JurnalistikIndonesia,
Menulis Beritadan Featrue; Panduan Praktis Jurnalis Profesional. Bandung: Simbiosa Rekatama Media.

Suryawati, Indah. 2011. Jurnalistik Suatu Pengantar; Teori dan Praktik. Bogor: Penerbit Ghalia Indonesia.

\section{Jurnal dan Penelitian}

Nuryanah, Yanty. 2017. Satir Dalam Kumpulan Cerpen Kuda Terbang Maria Pinto Karya Linda Christiany dan Implikasinya Terhadap Pembelajaran Bahasa dan Sastra Indonesia . Jakarta.

\section{Referensi Pendukung}

https://kbbi.web.id/komedidiaksespada8Maret 2019 pukul 15.57

https://kbbi.web.id/satirediakses pada 8 Maret 2019 pukul 15.59

https://tirto.id/kode-etik-jurnalistik-8Nb diakses pada 11 September 2019 pukul 15:17

ht tps://ww w. kompasiana.com/ teguh01190/5c21930baeebe15d1b63c767/ netralitas-media-dalam-kontestasi-politik2019? page $=$ all diakses pada 30 September 2019 pukul 12:08

https://www.merdeka.com/peristiwa/punya tanggung-jawab-besar-ke-publik-media-harusnetral-di-pemilu-2019.html diakses pada 30 September 2019 pukul 22:13 